\title{
REMOÇÃO DE TORUS MANDIBULAR PARA ENXERTO ÓSSEO EM MAXILA E COLOCAÇÃO DE IMPLANTE - RELATO DE CASO CLÍNICO
}

Vinycius Alessi MANEIRA, Eloá Cristine BERTONI, Eduardo MORESCHI, Vilmar GOTTARDO

A reabilitação estética e funcional despertou interesse para esclarecer métodos quantitativos de aumento de espessura dos rebordos maxilares após a realização de enxerto ósseo, visando futura reabilitação protética com implantes. Podem ser usados vários tipos de enxerto, porém o enxerto autógeno é considerado o "padrão ouro". Enxertos autógenos são utilizados rotineiramente na implantodontia, sendo que as principais áreas doadoras são a região de mento, corpo e ramo ascendente da mandíbula, além da espinha nasal e torus palatino ou mandibular. $O$ torus mandibular é considerado uma exostose, encontrado na região lingual da mandíbula, podendo se apresentar unilateral ou bilateral, com forma arredondada e uma superfície lisa, além de projeção óssea densa revestida por uma mucosa normal. É assintomático e não necessita de tratamento a não ser que ocorra desconforto do paciente ou para benefícios protéticos. Diante disso, o presente trabalho tem como objetivo o relato de caso clinico onde foi feita intervenção cirurgia para retirada em bloco do torus mandibular e enxerto ósseo em maxila para posterior colocação de implante, visto que o enxerto autógeno pode diminuir o risco de rejeição do organismo do paciente aumentando o índice de sucesso.

Palavras-chave: Osteotomia; Transplante ósseo; Exostose. 